\title{
Investigation of Strength and Durability Parameters for Metakaolin and GGBS Based Geoplolymer Concrete
}

\author{
M.V.Ramesh ${ }^{1}$, E.V.Chandra Sekhar ${ }^{2}$ \\ ${ }^{I}$ M.Tech Student, Department of Civil Engineering, Krishna chaitanya institute of technology and sciences, \\ Markapur, A. P, INDIA \\ ${ }^{2}$ Assosiate. Professor, Department of Civil Engineering, Krishna chaitanya institute of technology and sciences, \\ Markapur, A. P, INDIA
}

\begin{abstract}
The increasing emphasis on energy conservation and environmental protection has led to investigation of alternatives to customary building material. Effort are urgently underway all over the world to develop environment friendly construction materials which makes minimum utility of natural resources and helps to reduce green house gas emission Geopolymer concrete (GPC) is one of the most recently developed structural concretes, where industrial wastes like fly ash, rice husk, ground granulated blast furnace slag $(G G B S)$ are utilized for complete replacement of ordinary Portland cement in concrete. A major contribution to structural concrete in the form of Geopolymer concrete was developed by many investigators with lesser grade of concrete. The contribution of green house gas emission due to ordinary Portland cement production worldwide is approximately 7\%. For each ton of Portland cement manufactures, it is estimated that one ton of $\mathrm{CO}_{2}$ is released into the environment. In this connection, Geopolymer are showing great potential and does not need the presence of Portland cement as binder. Geopolymer concrete is prepared by using alkaline solution of suitable chemical composition. The ratio of mixture is 2.5 and the concentration of sodium hydroxide is 10M. The geo polymer concrete specimens are casted and tested for different types of strengths for 3, 7, and 28 days and cured at ambient temperature.
\end{abstract}

Keywords: Geo-polymer, Metakaolin, Ground Granulated Blast Furnace Slag, Alkali Activator.

\section{Introduction}

Geopolymer Concrete (GPC) is an efficient binder in the manufacturing of concrete technology. The source materials such as Metakaolin are treated with alkaline liquid to obtain the binder/adhesive agent. Geopolymer concrete will be introduced as an alternative concrete which did not use any cement in its mixture and used GGBS and Metakaolin as alternative cement. $\mathrm{NaOH}$ and $\mathrm{Na}_{2} \mathrm{SiO}_{3}$ were used as activator solution. Geopolymer cement is a state of art novelity and tend to create a platform for substitution with conventional manufacturing materials for architectural and construction industry. The concrete technology should tune on the lines of sustainability where the materials utilized in construction sector should be eco-friendly as well as facilitate the process of reuse if necessary. The integrated ecological based waste utilization finds its application ranging from small scale industries to large Power plants, etc. As a part of this novel idea, materials such as slag can be transformed in to geoploymer concrete or nowadays called as green concrete. Concrete is predominantly used material in architectural and construction industry ${ }^{1}$ The overall global production of cement is 2.8 billion tones according. ${ }^{2}$ A recent report to the United Nations Industrial Development Organization highlighted that as of $2005,60 \%$ of China's cement production was from Vertical Shaft Kilns (VSKs); characterized by low production efficiency ${ }^{3}$.The VSKs generally produced low quality cement unsuitable for large structures, infrastructure, or export. The emission of $\mathrm{CO}_{2}$ in the production of cement is due to clinker production, combustion of fuels in the cement kilns, and the use of energy for grinding raw material and clinker ${ }^{4-13}$. Abundant research has been conducted on newer concrete technologies and their use is seen in many construction solutions as they provide viable means of reducing the carbon footprint of concrete. ${ }^{5}$ the use of greener concrete is increasing day by day. A recent post-tensioned structure had concrete with $50 \%$ replacement of cement by slag for the slabs, columns, and walls; and $70 \%$ replacement in the mat foundation, resulting in an estimated reduction on carbon dioxide emissions for the project of 4500 tones (4400 tons). The latest research into the green concrete properties and it is extensive. Researchers have examined the durability and mechanical properties of concrete with fully replacement of cement by pozzolanic material. ${ }^{7,8}$ High volume substitutions for cement replacement results high strength and high durability concrete. ${ }^{9-18}$ the covalent bond between the oligomers tends to form a network and this process of combination results in what is known as geopolymerization. Refer Figure 1 shows the mixture of new product. 


\subsection{Met kaolin}

\section{Materials Used}

Metakaolin is one of the Pozzolanic materials used in concrete as a binder replaced by cement. It is suggested that firing kaolinite at lower temperatures $\left(<500{ }^{\circ} \mathrm{C}\right)$ does not give sufficient energy to break the crystalline structure of kaolinite. Refer Figure 2, 3, 4 and Table 1, 2

Table-1: Properties of Metakaolin

\begin{tabular}{|c|c|}
\hline Property & Value \\
\hline Specific Surface & $9-16 \mathrm{~m}^{2} / \mathrm{g}$ \\
\hline Physical Form & Powder \\
\hline Specific Gravity & 2.50 \\
\hline Color & Baby Pink \\
\hline
\end{tabular}

Table-2: Chemical Composition of metakaolin

\begin{tabular}{|c|c|}
\hline Oxide & \% \\
\hline $\mathrm{Al}_{2} \mathrm{O}_{3}$ & $42-44 \%$ \\
\hline $\mathrm{SiO}_{2}$ & $51-53 \%$ \\
\hline $\mathrm{TiO}_{2}$ & $<3.01 \%$ \\
\hline $\mathrm{Fe}_{2} \mathrm{O}_{3}$ & $<2.21 \%$ \\
\hline $\mathrm{SO}_{4}$ & $<0.51 \%$ \\
\hline $\mathrm{CaO}$ & $<0.22 \%$ \\
\hline $\mathrm{MgO}$ & $<0.11 \%$ \\
\hline $\mathrm{K}_{2} \mathrm{O}$ & $<0.43 \%$ \\
\hline $\mathrm{L} . \mathrm{O} . \mathrm{I}$ & $<0.51 \%$ \\
\hline $\mathrm{Na}_{2} \mathrm{O}$ & $<0.053 \%$ \\
\hline
\end{tabular}

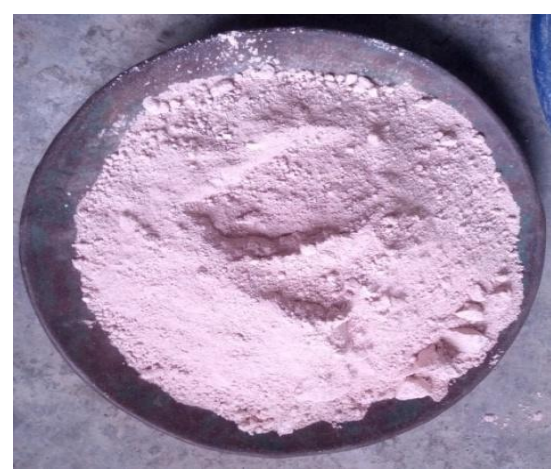

Figure 4: Metakaolin

\subsection{Ground Granulated Blast Funrace Slag:}

Ground Granulated Blast Furnace Slag (GGBS) is synthesized through the process of quenching. It is amorphous in nature and formed as a result of slag quenching from blast furnace. It can be seen as auxillary product during production of steel which can aid in concrete technology. Refer Figure 5, 6 and Table 3, 4

Table 3: Properties of Ground Granulated Blast Furnace Slag

\begin{tabular}{|c|c|}
\hline Property & Value \\
\hline Relative density & $2.85-2.95$ \\
\hline Bulk density (loose) & $1.0-1.1$ tonnes $/ \mathrm{m}^{3}$ \\
\hline Surface area & $400-600 \mathrm{~m}^{2} / \mathrm{kg} \mathrm{Blaine}$ \\
\hline Bulk density (vibrated) & $1.2-1.3$ tonnes $/ \mathrm{m}^{3}$ \\
\hline Colour & Off-white powder \\
\hline
\end{tabular}

Table-4: Chemical Composition of Ground Granulated Blast Furnace Slag

\begin{tabular}{|c|c|}
\hline Oxide & \% \\
\hline $\mathrm{CaO}$ & 36.77 \\
\hline $\mathrm{SiO}_{2}$ & 30.97 \\
\hline $\mathrm{Al}_{2} \mathrm{O}_{3}$ & 17.41 \\
\hline $\mathrm{MgO}$ & 9.01 \\
\hline $\mathrm{SO}_{3}$ & 1.82 \\
\hline $\mathrm{Fe}_{2} \mathrm{O}_{3}$ & 1.03 \\
\hline $\mathrm{Na}_{2} \mathrm{O}$ & 0.69 \\
\hline $\mathrm{K}_{2} \mathrm{O}$ & 0.46 \\
\hline
\end{tabular}




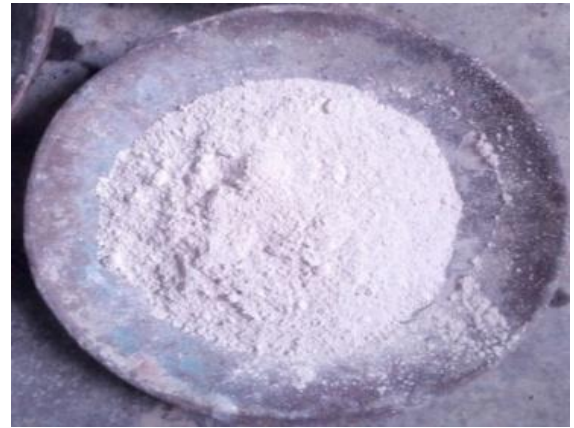

Figure 6: Ground Granulated Blast Furnace Slag

\subsection{Coarse Aggregate:}

Coarse aggregates of sizes $10 \mathrm{~mm}$ and $20 \mathrm{~mm}$ are taken. Refer Figure 7 and Table 5.

Table-5: I.S. Sieve specifications of Coarse Aggregate

\begin{tabular}{|c|c|c|c|c|}
\hline \multirow[b]{2}{*}{ IS Sieve No (mm) } & \multicolumn{2}{|c|}{$20 \mathrm{~mm}$} & \multicolumn{2}{|c|}{$10 \mathrm{~mm}$} \\
\hline & $\begin{array}{l}\text { Requirement as per } \\
\text { IS: } 383-1970\end{array}$ & $\begin{array}{c}\text { Percentage } \\
\text { passing }\end{array}$ & $\begin{array}{c}\text { Requirement } \\
\text { as per IS: 383- } \\
1970\end{array}$ & $\begin{array}{c}\text { Percentage } \\
\text { passing }\end{array}$ \\
\hline 80 & - & - & - & - \\
\hline 40 & $100 \%$ & $100 \%$ & - & - \\
\hline 20 & $95-100 \%$ & $96.52 \%$ & $95-100 \%$ & $95.6 \%$ \\
\hline 16 & - & - & $100 \%$ & $100 \%$ \\
\hline 10 & $0-20 \%$ & $13.72 \%$ & $0-45 \%$ & $41.52 \%$ \\
\hline Water absorption (\%) & \multicolumn{2}{|c|}{$0.35 \%$} & \multicolumn{2}{|c|}{$0.41 \%$} \\
\hline Specific gravity & \multicolumn{2}{|c|}{2.80} & \multicolumn{2}{|c|}{2.80} \\
\hline Bulk Density $\left(\mathrm{kg} / \mathrm{m}^{3}\right)$ & \multicolumn{2}{|c|}{1680} & \multicolumn{2}{|c|}{1513} \\
\hline Fineness modulus & \multicolumn{2}{|c|}{7.32} & \multicolumn{2}{|c|}{7.32} \\
\hline
\end{tabular}

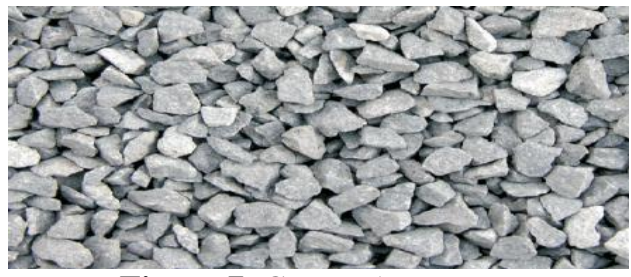

Figure 7: Coarse Aggregate

\subsection{Fine Aggregate:}

Fine Aggregate is generally sand whose properties are given in Refer Figure 8 and Table 6.

Table-6: I.S. sieve Specifications of Fine Aggregate

\begin{tabular}{|c|c|c|}
\hline \multirow{2}{*}{ Sieve Size (mm) } & Cumulative Passing (\%) & \multirow{2}{*}{ IS: 383-1970 - Zone II } \\
\cline { 2 - 3 } & F.A. & 100 \\
\hline 10 & 100 & $90-100$ \\
\hline 4.75 & 98.5 & $75-100$ \\
\hline 2.36 & 95.3 & $55-90$ \\
\hline 1.18 & 70.8 & $35-59$ \\
\hline $600(\mu \mathrm{m})$ & 46.5 & $8-30$ \\
\hline $300(\mu \mathrm{m})$ & 17.6 & $0-10$ \\
\hline $150(\mu \mathrm{m})$ & 3.21 & 3.12 \\
\hline Fineness modulus & \multicolumn{2}{|c|}{2.78} \\
\hline Specific Gravity & \multicolumn{2}{|c|}{$1375 \mathrm{Kg} / \mathrm{m}^{3}$} \\
\hline Bulk Density & \multicolumn{2}{|c}{} \\
\hline
\end{tabular}

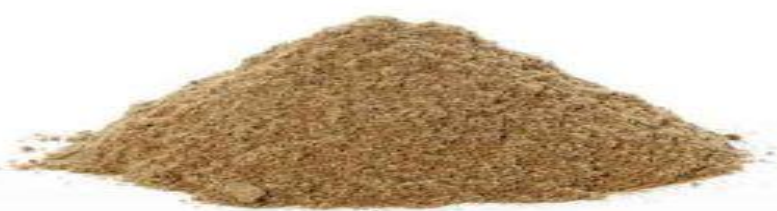

Figure 8: Fine Aggregate 


\subsection{Sodium Hydroxide:}

Sodium Hydroxide is the alkaline activator used in the process of geopolymerisation whose chemical properties are given in Refer Figure 9, 10 and Table 7.

Table 7: Properties of Sodium Hydroxide

\begin{tabular}{|c|c|}
\hline Property & Value \\
\hline Appearance & White \\
\hline Boiling point & $1,389^{\circ} \mathrm{C}$ \\
\hline Chemical formula & $\mathrm{NaOH}$ \\
\hline Solubility in water & $419 \mathrm{~g} / \mathrm{L}\left(0^{\circ} \mathrm{C}\right)$ \\
& $1111 \mathrm{~g} / \mathrm{L}\left(20^{\circ} \mathrm{C}\right)$ \\
& $3371 \mathrm{~g} / \mathrm{L}\left(100^{\circ} \mathrm{C}\right)$ \\
\hline Molar mass & $40 \mathrm{~g} \mathrm{~mol}^{-1}$ \\
\hline Odor & Odorless $^{\circ}$ \\
\hline Melting point & $318^{\circ} \mathrm{C}$ \\
\hline Density & $2.14 \mathrm{~g} / \mathrm{cm}^{3}$ \\
\hline
\end{tabular}

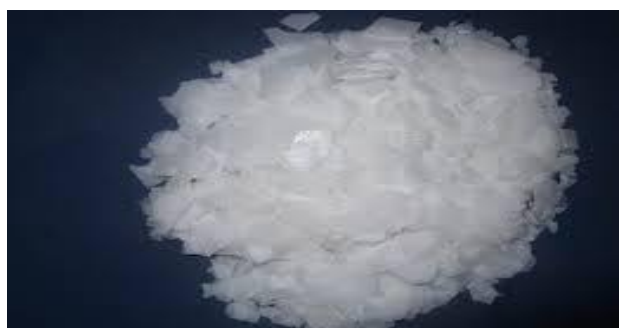

Figure 9: Sodium Hydroxide Flakes

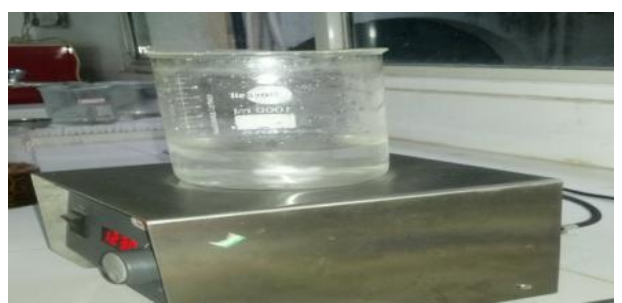

Figure 10: Sodium Hydroxide Solution

\subsection{SODIUM SILICATE $\left(\mathrm{Na}_{2} \mathrm{Sio}_{3}\right)$ :}

Sodium Silicate is the common name for compounds with the formula $\mathrm{Na}_{2}\left(\mathrm{SiO}_{2}\right)_{\mathrm{n}} \mathrm{O}$. Refer Figure $11,12,13$ and Table 8.

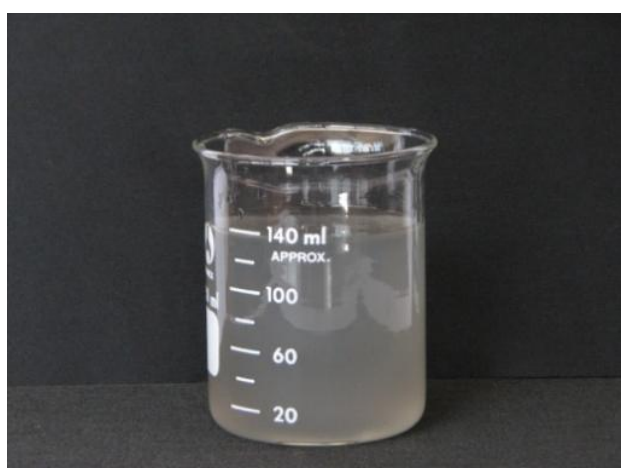

Figure 11: Solution of Sodium Silicate

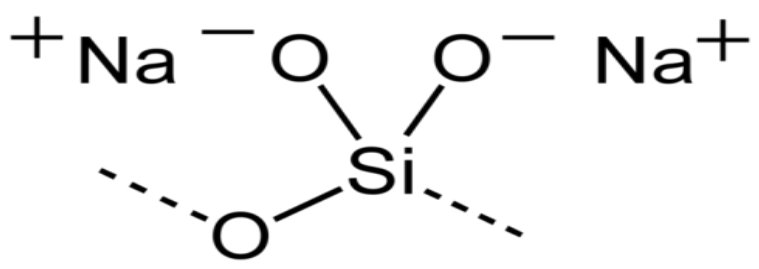

Figure 12: Sodium Silicate Structure 


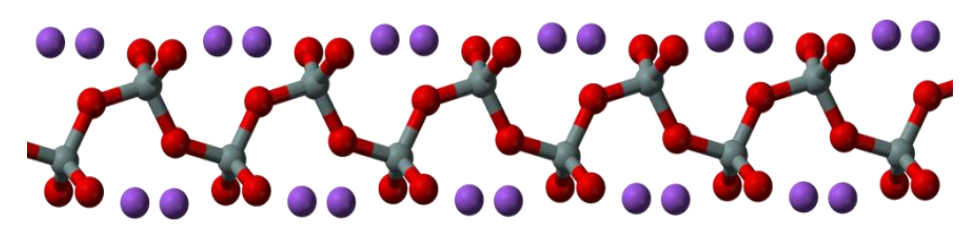

Figure 13: 3-D Structure of sodium silicate

Table-8: Properties of Sodium Silicate

\begin{tabular}{|c|c|}
\hline Property & Value \\
\hline Solubility in water & $22.2 \mathrm{~g} / 100 \mathrm{ml}\left(25^{\circ} \mathrm{C}\right)$ \\
& $160.6 \mathrm{~g} / 100 \mathrm{ml}\left(80^{\circ} \mathrm{C}\right)$ \\
\hline Refractive index $\left(n_{\mathrm{D}}\right)$ & 1.52 \\
\hline Appearance & White to greenish $^{\mathrm{Na}_{2} \mathrm{SiO}_{3}}$ \\
\hline Chemical formula & $2.62 \mathrm{~g} \mathrm{~cm}^{-3}$ \\
\hline Density & $1,089{ }^{\circ} \mathrm{C}$ \\
\hline Melting point & insoluble in alcohol \\
\hline Solubility & alch
\end{tabular}

2.7 Sodium Sulfate $\left(\mathrm{Na}_{2} \mathrm{So}_{4}\right)$ :

Sodium sulfate is the inorganic compound with formula $\mathrm{Na}_{2} \mathrm{SO}_{4}$ is used in the process of green concrete technology. Refer Figure 13, 14 and Table 9.

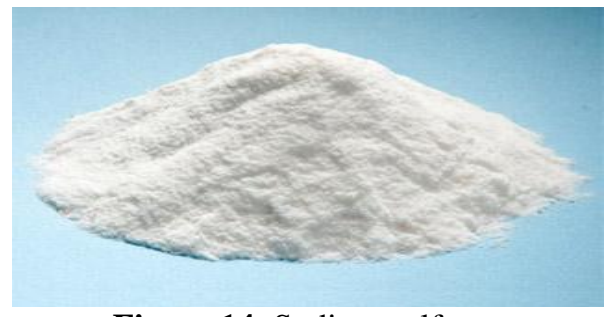

Figure 14: Sodium sulfate

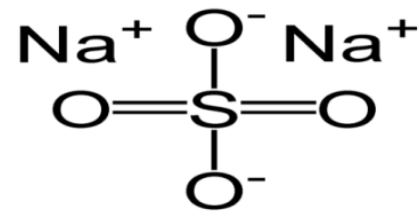

Figure 15: Sodium Sulphate structure

Table-9: Durability Parameters

\begin{tabular}{|c|c|c|c|c|}
\hline S. no & Parameters to study & $\begin{array}{c}\text { Volume of Specimen in } \\
\mathrm{mm}\end{array}$ & $\begin{array}{c}\text { Chemical for } \\
\text { curing }\end{array}$ & $\begin{array}{c}\text { No of } \\
\text { specimens }\end{array}$ \\
\hline 1 & $\begin{array}{c}\text { Chang in compressive } \\
\text { strength }\end{array}$ & $150 X 150 X 150$ & Sodium Sulphate & 9 \\
\hline 2 & Change in mass & $150 X 150 X 150$ & Sodium Sulphate & 9 \\
\hline
\end{tabular}

\subsection{Geopolymer Concrete MIX:}

\section{Methodology}

Initially dry mix, fine as well as coarse aggregate, alkaline solution and Pozzolanic material (Metakaolin + GGBS) are combined. About 6 to 8 minutes spent for mixing of concrete to achieve proper bonding of materials. Later, mixing Cubes, beams, cylinders with sizes $150 \mathrm{~mm} \mathrm{X} \mathrm{150mm} \mathrm{X} \mathrm{150mm,} \mathrm{500mm} \mathrm{X}$ $100 \mathrm{~mm} \times 100 \mathrm{~mm}$, and $150 \mathrm{~mm}$ dia $300 \mathrm{~mm}$ height are casted and compacted properly. In this project ambient curing is chosen for curing of geo-polymer concrete. For ambient curing, cubes are un-moulded after 24 hours of casting and they are placed in the direct sunlight for 72 hours. Refer Table 10, 11, 12. 
Table 10: Mixing Proportion of Geopolymer concrete

\begin{tabular}{|c|c|c|c|c|c|c|c|}
\hline \multirow{2}{*}{\multicolumn{2}{|c|}{$\begin{array}{l}\text { Ingredients in } \\
\left(\mathrm{kg} / \mathrm{m}^{3}\right)\end{array}$}} & \multicolumn{6}{|c|}{ Different mixes } \\
\hline & & $\mathbf{C}_{1}$ & $\mathbf{C}_{2}$ & $\mathbf{C}_{3}$ & $\mathbf{C}_{4}$ & $\mathbf{C}_{5}$ & $\mathrm{C}_{6}$ \\
\hline \multicolumn{2}{|c|}{ Pozzolanic Material } & 414 & 414 & 414 & 414 & 414 & 414 \\
\hline \multicolumn{2}{|c|}{ Metakaolin } & 207 & 248 & 290 & 331 & 373 & 414 \\
\hline \multicolumn{2}{|c|}{$\begin{array}{c}\text { Ground Granulated Blast } \\
\text { Furnace Slag }\end{array}$} & 207 & 166 & 124 & 83 & 41 & 0 \\
\hline \multirow{2}{*}{$\begin{array}{c}\text { Coarse } \\
\text { Aggregate }\end{array}$} & $10 \mathrm{~mm}$ & 467 & 467 & 467 & 467 & 467 & 466 \\
\hline & $20 \mathrm{~mm}$ & 699 & 699 & 699 & 699 & 699 & 699 \\
\hline \multicolumn{2}{|c|}{ Fine Aggregate } & 660 & 660 & 660 & 660 & 660 & 660 \\
\hline \multicolumn{2}{|c|}{ Sodium Hydroxide Solution } & 53 & 53 & 53 & 53 & 53 & 53 \\
\hline \multicolumn{2}{|c|}{ Sodium Silicate Solution } & 133 & 133 & 133 & 133 & 133 & 133 \\
\hline
\end{tabular}

\section{STRENGTH:}

The experimental investigation processed by taking six pozzolanic Proportions pictured in above table in the aspects of Compressive, Split Tensile, and Flexural strengths where proportions starts from $50 \%$ Metakaolin $+50 \%$ GGBS to $100 \%$ Metakaolin.

Table-11: Mix ID of Pozzolanic Material Proportions for Strength properties

\begin{tabular}{|c|c|c|}
\hline Mix ID & Metakaolin (\%) & Ground Granulated Blast Furnace Slag (\%) \\
\hline $\mathrm{C}_{1}$ & 50 & 50 \\
\hline $\mathrm{C}_{2}$ & 60 & 40 \\
\hline $\mathrm{C}_{3}$ & 70 & 30 \\
\hline $\mathrm{C}_{4}$ & 80 & 20 \\
\hline $\mathrm{C}_{5}$ & 90 & 10 \\
\hline $\mathrm{C}_{6}$ & 100 & 0 \\
\hline
\end{tabular}

\section{Durability:}

The experimental investigation Processed by taking 3 Pozzolanic Proportions C1, C3, C6 pictured in above table in the aspects of Durability

Table-12: Mix ID of Pozzolanic Material Proportions for Durability Properties

\begin{tabular}{|c|c|c|}
\hline Mix ID & Metakaolin (\%) & Ground Granulated Blast Furnace Slag (\%) \\
\hline $\mathrm{C}_{1}$ & 50 & 50 \\
\hline $\mathrm{C}_{3}$ & 70 & 30 \\
\hline $\mathrm{C}_{6}$ & 100 & 0 \\
\hline
\end{tabular}

\section{Results \& Discussions}

The cubes, beams, cylinder specimens have undergone the process of testing using standard equipment to determine compressive, flexural and split tensile strengths at the age of 3, 7, and 28 days. The figures 5, 6 and 7 are showing the graphical and table 13,15,16 shows tabular representation of various strengths with 10 Molarity alkali activator for the specimens which were cured in sunlight.

\subsection{Compressive Strength:}

The compressive strength of concrete with different proportions are casted of age 3, 7 and 28 days and a graph is plotted between pozzolanic material proportion(x-axis) Vs compressive strength (y-axis). From the figure we can say, as the age of concrete increases compressive strength increases. 100\% Metakaolin gives compressive strength of $60.03 \mathrm{~N} / \mathrm{mm}^{2}$ which is the maximum strength obtained than other proportions. The strength variation between one proportion to other and one age to other is in slight manner. Refer Figure 16, 17 and Table 13

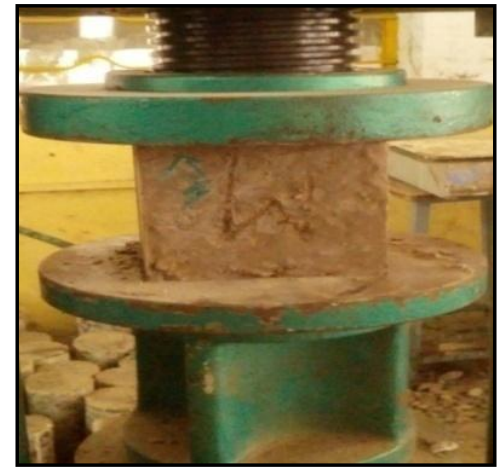

Figure 16: Compression test of Geopolymer concrete 
Table-13: Compressive Strength of Geopolymer cocnrete

\begin{tabular}{|c|c|c|c|c|c|}
\hline \multirow{2}{*}{ Mix ID } & \multicolumn{2}{|c|}{ POZZOLANIC MATERIAL PROPORTION } & \multicolumn{3}{|c|}{ COMPRESSIVE STRENGTH $\left(\mathrm{N} / \mathrm{mm}^{2}\right)$} \\
\cline { 2 - 6 } & $\begin{array}{c}\text { Metakaolin } \\
(\%)\end{array}$ & $\begin{array}{c}\text { GGBS } \\
(\%)\end{array}$ & 3 DAYS & 7 DAYS & 28 DAYS \\
\hline C1 & 50 & 50 & 31.23 & 34.12 & 35.23 \\
\hline C2 & 60 & 40 & 34.20 & 35.72 & 39.29 \\
\hline C3 & 70 & 30 & 42.14 & 44.32 & 48.13 \\
\hline C4 & 80 & 20 & 44.91 & 46.94 & 50.28 \\
\hline C5 & 90 & 10 & 51.3 & 53.91 & 56.71 \\
\hline C6 & 100 & 0 & 53.62 & 54.64 & 61.03 \\
\hline
\end{tabular}

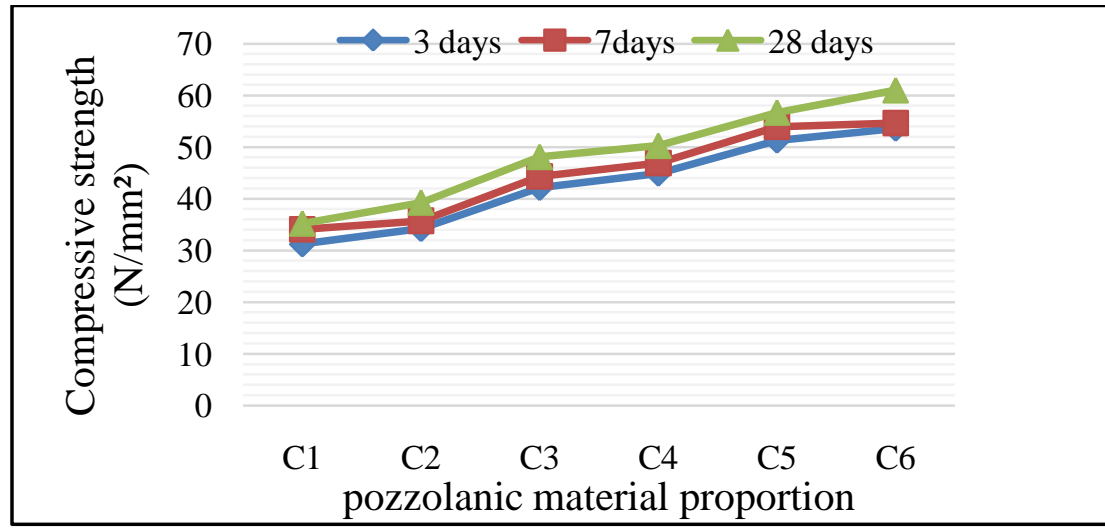

Figure 17: Graph between Compressive Strength and Pozzolanic Material Proportions

\subsection{Split Tensile Strength:}

The Split Tensile Strength of GPC with different proportions are obtained of age 3, 7 and 28 and a graph is plotted between pozzolanic material proportion (x-axis) vs split tensile strength (y-axis). From the figure we can say, as the age of concrete increases tensile strength increases. $100 \%$ Metakaolin gives strength of $6.73 \mathrm{~N} / \mathrm{mm}^{2}$ which is the maximum strength obtained than other proportions. The strength variation between one proportion to other and one age to other is in slight manner. Refer Figure 18, 19 and Table 14

Table-14: Split Tensile Strength of Geopolymer Concrete

\begin{tabular}{|c|c|c|c|c|c|}
\hline \multirow{2}{*}{ Proportion } & \multicolumn{2}{|c|}{ POZZOLANIC MATERIAL } & \multicolumn{2}{c|}{ SPLIT TENSILE STRENGTH (N/mm $\left.{ }^{2}\right)$} \\
\cline { 2 - 5 } & $\begin{array}{c}\text { Metakaolin } \\
(\%)\end{array}$ & $\begin{array}{c}\text { GGBS } \\
(\%)\end{array}$ & 3 DAYS & 7 DAYS & 28 DAYS \\
\hline C1 & 50 & 50 & 3.12 & 3.72 & 3.9 \\
\hline C2 & 60 & 40 & 3.70 & 3.81 & 4.14 \\
\hline C3 & 70 & 20 & 4.92 & 3.98 & 4.23 \\
\hline C4 & 80 & 10 & 5.26 & 5.67 & 4.71 \\
\hline C5 & 90 & 0 & 6.22 & 6.53 & 6.73 \\
\hline C6 & 100 & & & & \\
\hline
\end{tabular}

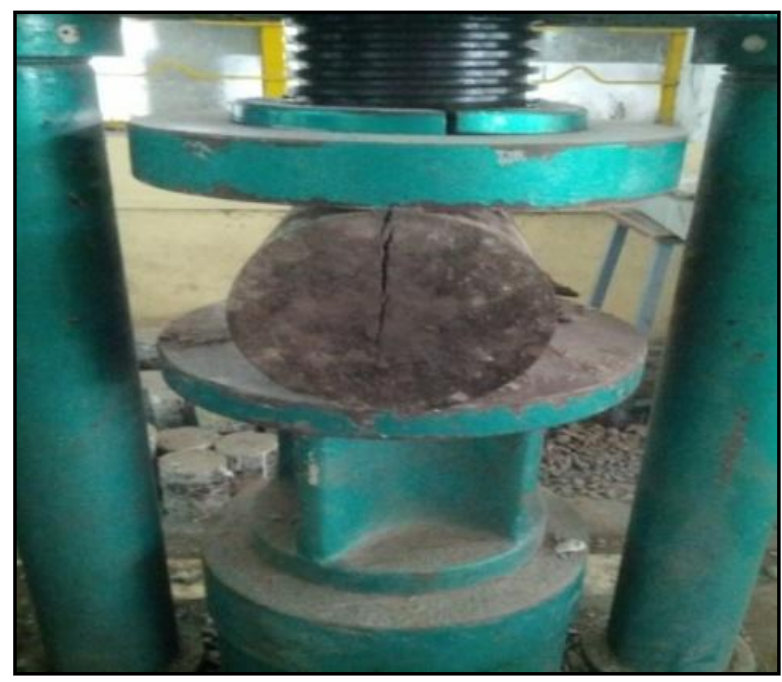

Figure 18: Split Tensile Test of Geopolymer concrete 


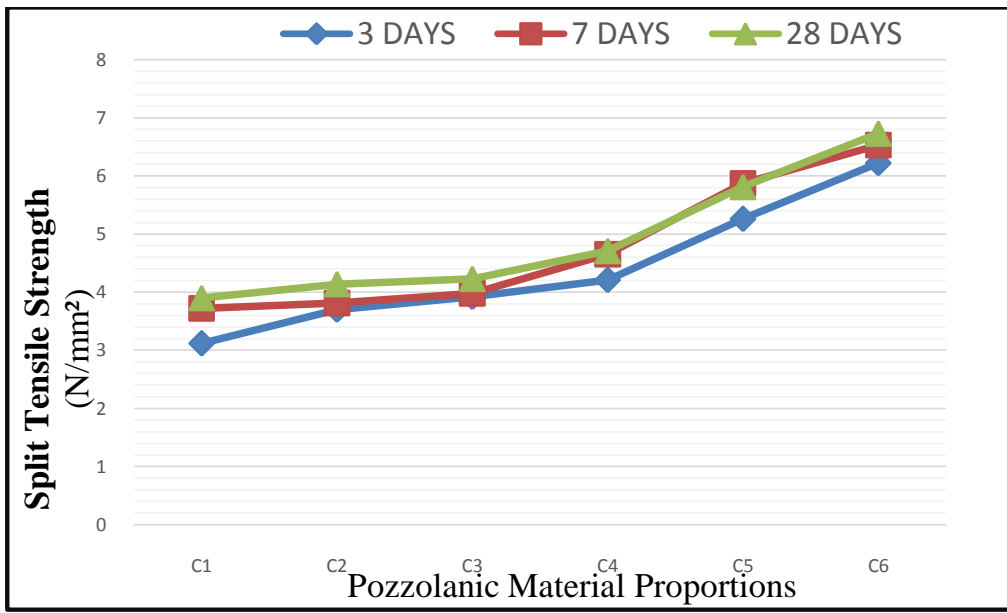

Figure 19: Graph between Split tensile Strength and Pozzolanic Material Proportions

\subsection{Flexural Strength:}

The Flexural strength of concrete with different proportions are evaluated of age 3, 7 and 28 days and a graph is plotted between pozzolanic material proportion (x-axis) vsFlexural strength (y-axis).A two point load is applied on the beams of size $50 \mathrm{~mm}$ in length, $10 \mathrm{~mm}$ in width and $10 \mathrm{~mm}$ in depth. From the figure we can say, as the age of concrete increases Flexural strength increases. 100\% Metakaolin gives Flexural strength of 3.54 $\mathrm{N} / \mathrm{mm}^{2}$ which is the maximum strength obtained than other proportions. The strength variation of $\mathrm{C} 1, \mathrm{C} 2, \mathrm{C} 3$ and $\mathrm{C} 4$ are slight but C5, C6 has vast variation. Refer Figure 20 and Table 15

Table-15: Flexural Strength of Geopolymer concrete

\begin{tabular}{|c|c|c|c|c|c|}
\hline \multirow{2}{*}{ Proportion } & \multicolumn{2}{|c|}{$\begin{array}{c}\text { POZZOLANIC } \\
\text { MATERIAL }\end{array}$} & \multicolumn{3}{c|}{ FLEXURAL STRENGTH } \\
& (N/mm $\left.{ }^{2}\right)$ \\
\cline { 2 - 6 } & $\begin{array}{c}\text { Metakaolin } \\
(\%)\end{array}$ & $\begin{array}{c}\text { GGBS } \\
(\%)\end{array}$ & 3 DAYS & $\begin{array}{c}7 \\
\text { DAYS }\end{array}$ & $\begin{array}{c}28 \\
\text { DAYS }\end{array}$ \\
\hline C1 & 50 & 50 & 0.75 & 0.822 & 0.87 \\
\hline C2 & 60 & 40 & 0.85 & 0.9 & 1.2 \\
\hline C3 & 70 & 30 & 1.11 & 1.58 & 1.75 \\
\hline C4 & 80 & 20 & 1.63 & 1.67 & 1.71 \\
\hline C5 & 90 & 10 & 1.96 & 2.57 & 2.81 \\
\hline C6 & 100 & 0 & 3.2 & 3.41 & 3.54 \\
\hline
\end{tabular}

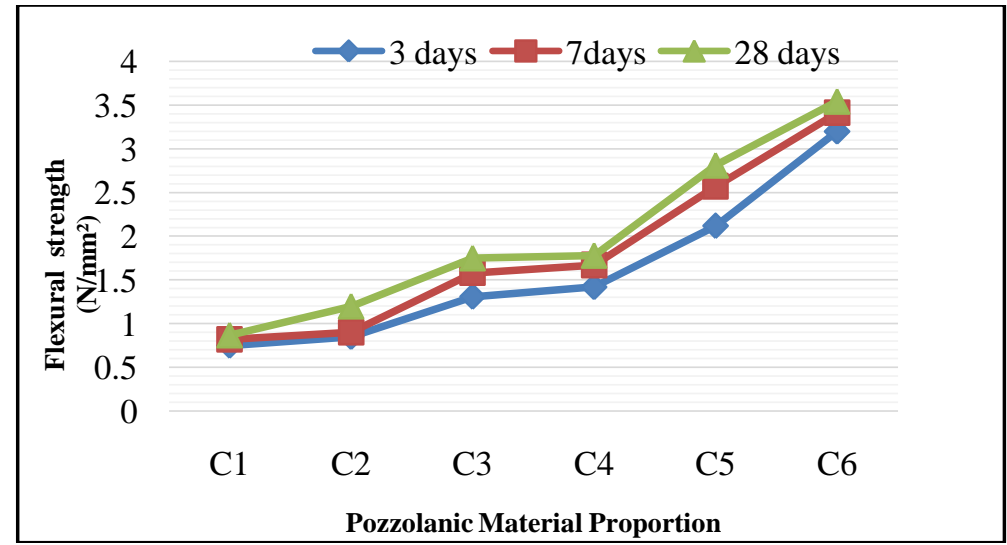

Figure 20: Graph between Flexural Strength and Pozzolanic Material Proportions

\section{Durability:}

Durability is a major factor to be considered for the structure to with stand for a long period i.e. the age of the structure should be more durable. So my experimental investigation take me to identify the structural behavior on different environmental like Chloride attack, Acid attack and Sulphate attack. But in this report work is concentrated on sulphate attack. Therefore the results and discussions are processed as follows. Refer Figure 21, 22, 23 and Table 16, 17 
- The initial compressive strengths are obtained from the proportions $\mathrm{C} 1, \mathrm{C} 3, \mathrm{C} 6$ which are in ambient curing for 28 days.

- The final compressive strengths are obtained from the proportions $\mathrm{C} 1, \mathrm{C} 3, \mathrm{C} 6$ which are in chemical curing for 30 days and dried for 15 day

Table-16: Percentage Reduction in weight

\begin{tabular}{|c|c|c|c|c|c|c|}
\hline S.no & \multirow{2}{*}{$\begin{array}{c}\text { Mix } \\
\text { ID }\end{array}$} & \multicolumn{2}{|c|}{$\begin{array}{c}\text { Weight of Specimens } \\
\text { (grams) }\end{array}$} & $\begin{array}{c}\text { Reduction in } \\
\text { weight } \\
\text { (grams) }\end{array}$ & $\begin{array}{c}\text { \% Reduction } \\
\text { in weight }\end{array}$ & $\begin{array}{c}\text { No. of } \\
\text { days }\end{array}$ \\
\cline { 3 - 4 } & & Initial & Final & 60 & 0.73 & 20 \\
\hline 1 & $\mathrm{C}_{1}$ & 8193 & 8133 & 61 & 0.68 & 20 \\
\hline 2 & $\mathrm{C}_{3}$ & 8856 & 8795 & 67 & 0.66 & 20 \\
\hline 3 & $\mathrm{C}_{6}$ & 8543 & 8486 & 57 & \\
\hline
\end{tabular}

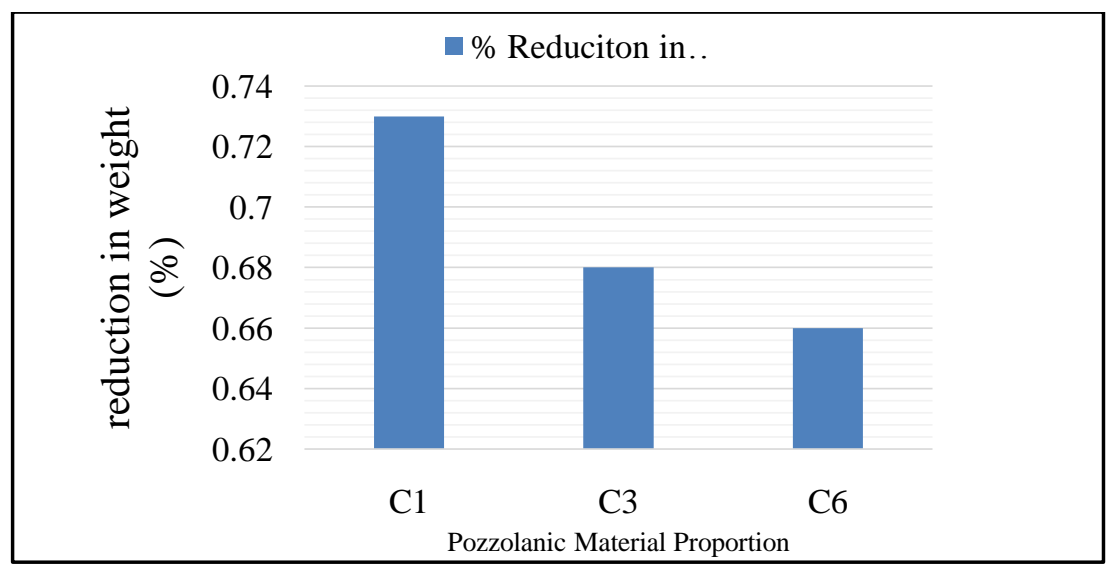

Figure 21: Graph between Pozzolanic Material and \% Weight Reduction
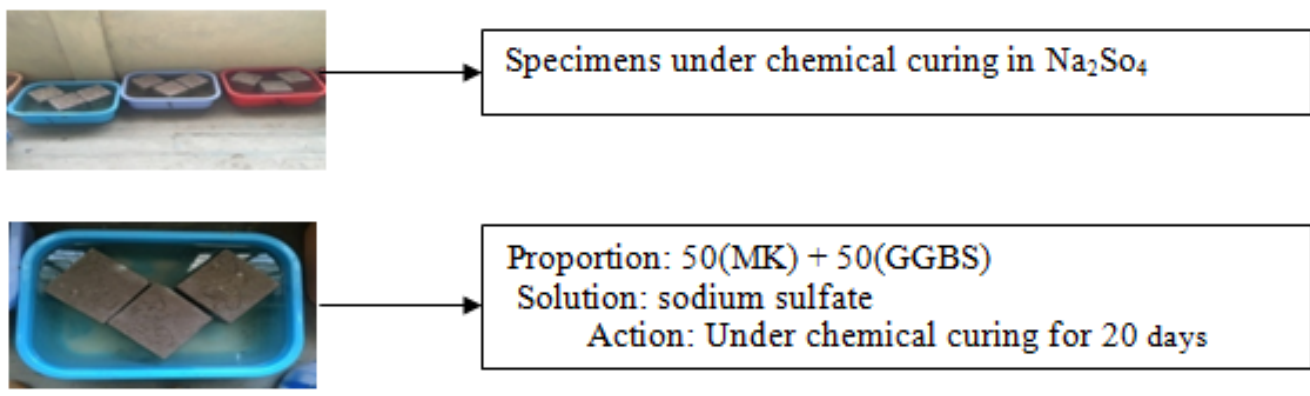

Proportion: 50(MK) + 50(GGBS)

Solution: sodium sulfate

Action: Under chemical curing for 20 days

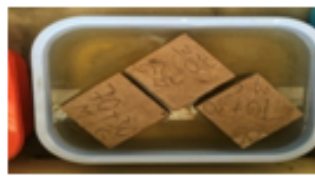

\section{Proportion: 70(MK) + 30(GGBS)}

Solution: sodium sulfate

Action: Under chemical curing for 20 days

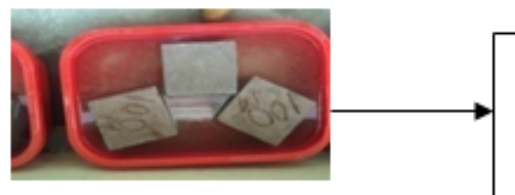

Proportion: $100(\mathrm{MK})+0$ (GGBS)

Solution: sodium sulfate

Action: Under chemical curing for 20 days

Table-17: Compressive strength of Geopolymer Concrete after exposure to sulfate solution

\begin{tabular}{|c|c|c|c|c|c|}
\hline S.no & MIX ID & \multicolumn{2}{|c|}{$\begin{array}{c}\text { Compressive strength } \\
\left(\mathrm{N} / \mathrm{mm}^{2}\right)\end{array}$} & $\begin{array}{c}\% \\
\text { Reduction } \\
\text { in C.S }\end{array}$ & $\begin{array}{c}\text { No. of days for } \\
\text { chemical curing }\end{array}$ \\
\cline { 3 - 4 } & & Initial & Final & 11.75 & 20 \\
\hline 1 & $\mathrm{C}_{1}$ & 35.23 & 31.09 & 8.83 & 20 \\
\hline 2 & $\mathrm{C}_{3}$ & 48.13 & 43.88 & 15.28 & 20 \\
\hline 3 & $\mathrm{C}_{6}$ & 61.03 & 51.70 & & \\
\hline
\end{tabular}




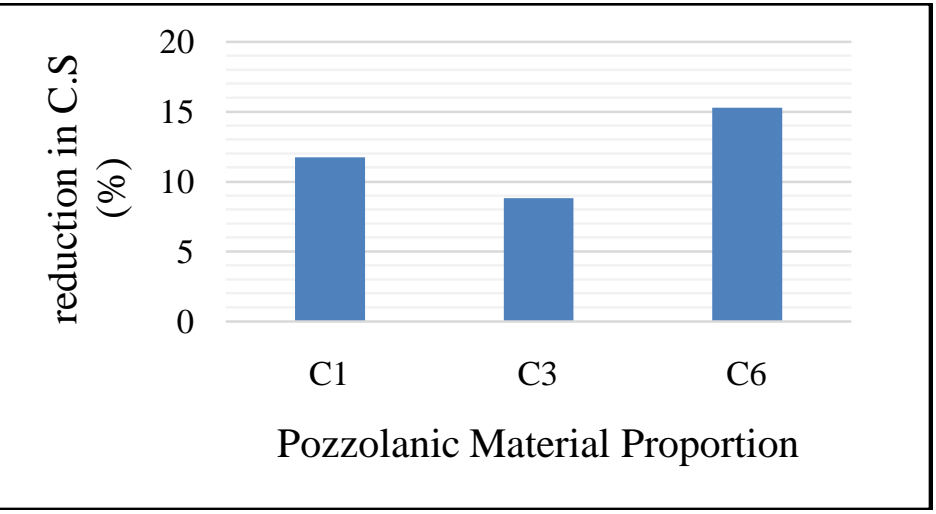

Figure 23: Graph between Pozzolanic proportion and \% Reduction in Compressive strength.

\section{Conclusion}

- From the above results it is apparent that Geopolymer concrete based on GGBS and metakaolin has got more compressive strength than conventional concrete.

- It is observed that the Compressive, Flexural and Split Tensile strengths of Geopolymer Concrete are increased with increase in percentage of Metakaolin quantity i.e GGBS 0\%-MK 100\% and decreased with increase in GGBS irrespective of curing period.

- The green concrete resists the attack of various chemicals and therefore, it is durable for the given mix proportion.

- Compressive, Flexural and split tensile strengths vary in direct relation to age for a given proportion of a mix.

- Proportion $\mathrm{C}_{1}$ obtained the maximum in percentage reduction of 0.73 in weight for 30 days of chemical curing $\left(\mathrm{Na}_{2} \mathrm{SO}_{4}\right)$.

- Proportion $\mathrm{C}_{6}$ obtained the maximum in percentage reduction of 15.28 in Compressive strength for 30 days of chemical curing $\left(\mathrm{Na}_{2} \mathrm{SO}_{4}\right)$.

\section{References}

[1]. Aswathy Kurian, Binu M Issac, Soumya Anand. An Experimental Study on Geopolymer Concrete with the Partial Replacement of Coarse Aggregate with Laterite. Internation Conference on Science, Technology and Management. 2015 september.

[2]. Ambroise J, Maximilien S, Pera J. Properties of metakaolin blended cements. Advanced Cement Based Materials. 1994 May; 1(4), 161-168.

[3]. Asbridge A H, Chadbourn G A, Page, C L. Effects of Metakaolin and the Interfacial Transition Zone on the Diffusion of Chloride Ions Through Cement Mortars. Cement and Concrete Research. 2001 November; 31(11), 1567-1572.

[4]. Bai J, Wild S. Investigation of the Temperature Change and Heat Evolution of Mortar Incorporating PFA and Metakaolin. Cement and Concrete Composites 2002; 24(2), 201-209.

[5]. Batis G, Pantazopoulou P, Tsivilis S, Badogiannis E, The effect of metakaolin on the corrosion behavior of cement mortars. Cement and Concrete Composites in press 2005 january; 27(1), 125-130.

[6]. Bensted J, Barnes P in Structure and Performance of Cements. $2^{\text {nd }}$ ed. Taylor and Francis Publication: New York, 2002.

[7]. Bentz D P, Garboczi C J, Haecker C J, Jensen O M. Effects of cement particle size distribution on performance properties of portland cement-based materials, Cement and Concrete Research. 1999 october; 29(10), 1663-1671.

[8]. Bérubé M, Duchesne J, Chouinard D, Why the accelerated mortar bar method ASTM C 1260 is reliable for evaluating the effectiveness of supplementary cementing materials in suppressing expansion due to alkali-silica reactivity. Cement, Concrete, and Aggregates, 1995 june; 17(1), 26-34.

[9]. Bhadeshia, H.K.D.H., An Introduction to Thermal Analysis Techniques, http://www.msm.cam.ac.uk/phasetrans/2002/thermal.analysis.html, accessed October 2004.

[10]. Boddy A, Hooton R D, Gruber K A. Long-term testing of the chloride penetration resistance of concrete containing highreactivity metakaolin. Cement and Concrete Research. 2001 May; 31(5), 759-765.

[11]. Brinkley G W. Ceramic Fabrication Processes, Technology Press \& John Wiley and Sons: Cambridge \& New York, 1985.

[12]. Cabrera J G, Lee R E. A new method for for the measurement of workability of high-pulverised fuel ash concrete. International Ash Utilization Symposium. 1985; 347-360.

[13]. Caldarone M A, Gruber K A and Burg R G, High reactivity metakaolin (HRM): a new generation mineral admixture for high performance concrete. Concrete International. 1994 january; 16(11), 37-40.

[14]. Courard L, Darimont A, Schouterden M, Ferauche F, Willem X, Degeimbre R, Durability of mortars modified with metakaolin. Cement and Concrete Research. 2003 September; 33(9), 1473-1479.

[15]. Curcio F, DeAngelis B A, Pagliolico S. Metakaolin as a pozzolanic micro filler for high-performance mortars. Cement and Concrete Research. 1998 june; 28(6), 803-809.

[16]. Rajini B, Narasimha A V. Mechanical Properties of Geopolymer Concrete with Fly Ash and GGBS as Source Materials. International Journal of Innovative Research in Science, Engineering and Technology. 2014 September; 3(9), 15944-15953

[17]. DiamondS.Mercuryporosimetry: an inappropriate method for the measure-ment of pore size distributions in cement-based materials. Cement and Concrete Research. 2000 october; 30(10), 1517-1525.

[18]. Ding J T, Li Z J. Effects of metakaolin and silica fume on properties of concrete. ACI Materials Journal. 2002 August; 99(4), 393-398. 